\title{
CORN GERM MEAL AS SUBSTITUTE FOR CORN IN THE DIET OF CONFINED SANTA INÊS SHEEP: CHEMICAL AND LIPID MEAT COMPOSITION
}

\author{
Gérmen do milho como substituto ao milho na dieta de ovinos Santa Inês \\ confinados: composição química e lipídica da carne
}

\author{
Stela Antas Urbano ${ }^{1}$, Marcelo de Andrade Ferreira ${ }^{2}$, Marta Suely Madruga ${ }^{3}$, \\ Paulo Sérgio de Azevedo ${ }^{4}$, Safira Valença Bispo ${ }^{4}$, Emmanulle Cordeiro da Silva ${ }^{2}$
}

\begin{abstract}
The per capita consumption of sheep meat in Brazil is still small compared to meat originating from other animal species, the lipid profile of meat named as responsible for reduced consumption. Despite the influence of sex, breed, weight at slaughter and environment, diet is seen as a major factor influencing the lipid composition of sheep meat. This study evaluated the effect of replacing corn by corn germ meal $(0,25,50,75$ and $100 \%)$ in the diet of Santa Inês sheep on the meat's chemical and lipid composition. Forty non-emasculated animals were distributed in a randomized block experimental design, with five treatments and eight replications, and slaughtered after 70 days of confinement. There was no influence of the substitution on the meat's chemical composition. No effects on the total saturated fatty acids (SFA) were observed, but there was a decreasing linear effect on the total monounsaturated fatty acids (MFA) and an increasing linear effect on the total polyunsaturated fatty acids (PFA). The PFA:SFA and $\omega-6: \omega-3$ ratios increased with the substitution level. Corn germ meal had no effect on the meat's chemical composition, but improved the nutritional quality of the lipid fraction, enriching it with compounds beneficial for human health.
\end{abstract}

Index terms: CLA, co-products, lipid profile.

\section{RESUMO}

O consumo per capta de carne ovina no Brasil ainda é pequeno quando comparado às carnes oriundas de outras espécies animais, sendo o perfil lipídico da carne apontado como responsável pelo consumo reduzido. Apesar de sofrer influência de sexo, raça, peso ao abate e ambiente, a dieta é tida como principal fator que influencia a composição lipídica da carne ovina. Avaliou-se o efeito da substituição do milho pelo gérmen integral de milho na dieta de ovinos da raça Santa Inês sobre a composição química e lipídica da carne. Quarenta animais não castrados da raça Santa Inês foram distribuídos em delineamento inteiramente casualizado, com cinco tratamentos e oito repetições, e abatidos após 70 dias de confinamento. Não houve influência sobre a composição química da carne. Não houve efeito sobre o total de ácidos graxos saturados (AGS), mas verificou-se efeito linear decrescente para o total de ácidos graxos monoinsaturados e crescente para o total de ácidos graxos poli-insaturados (AGP). As relações AGP:AGS e $\omega$-6: $\omega-3$ elevaram-se com a substituição. O gérmen integral de milho não influencia a composição química da carne, mas melhora a qualidade nutricional da fração lipídica, enriquecendo-a com compostos benéficos à saúde humana.

Termos para indexação: CLA, co-produtos, perfil lipídico.

\section{INTRODUCTION}

The per capita consumption of sheep meat in Brazil is still small when compared with the consumption of poultry, pig and bovine meat, regardless of the considerable growth of the sheep effective observed during the past decade. The increase of this consumption directly depends on the regular supply and the quality of the product available to the consumer, which currently demands sheep meat with standardized quality, without excessive fat, and with a high level of softness.

The fat in the adipose deposits of ruminants is rich in triglycerides, mainly saturated fatty acids, with low quantities of polyunsaturated fatty acids. This lipid profile has been responsible for the decrease in consumption of meat and meat derivatives in some countries (Bas et al., 2007), due to the strong relation between the quality of ingested fat and human health (Rioux, Legrand, 2007). Human nutritionists recommend an increase in

\footnotetext{
${ }^{1}$ Universidade Federal Rural de Pernambuco/UFRPE - Departamento de Zootecnia - Rua Dom Manoel de Medeiros - s/n - Dois Irmãos - Recife - PE - Brasil - 52171-900 - stela_antas@yahoo.com.br

${ }^{2}$ Universidade Federal Rural de Pernambuco/UFRPE - Departamento de Zootecnia - Recife - PE - Brasil

3Universidade Federal da Paraíba/UFPB - Departamento de Engenharia de Alimentos - João Pessoa - PB - Brasil

${ }^{4}$ Universidade Federal da Paraíba/UFPB - Departamento de Zootecnia - João Pessoa - PB - Brasil

Received in june 24, 2014 and approved in september 1, 2014
} 
polyunsaturated fatty acid consumption, mostly of the $\omega-6$ and $\omega-3$ classes. Animal science researchers therefore seek to decrease the saturated/polyunsaturated fatty acid ratio and the balance of the $\omega-6 / \omega-3$ ratio, while increasing the conjugated linoleic acid (CLA) concentrations in the lipid fraction of ruminant meat (Raes, Smet, Demeyer, 2004). Although the lipid profile of sheep meat varies with the race, gender, slaughter weight and environment, diet has been cited as the main factor influencing the lipid composition of sheep meat (Wood et al., 2004).

The goal of this work was to evaluate the effect of replacing corn with corn germ meal on the chemical and lipid composition and the physicochemical parameters of meat from Santa Inês sheep raised in confinement.

\section{MATERIALS AND METHODS}

The meat samples used in this study originated from 40 non-emasculated Santa Inês sheep, at five months of age and an initial weight of $17.0 \pm 2.5$ $\mathrm{kg}$, used in a performance assay conducted by Silva et al. (2013) at the Department of Animal Science of the Universidade Federal Rural de Pernambuco, located in Recife, State of Pernambuco (PE), Brazil), where the nutrient consumption, digestibility and performance were evaluated. The percentage and chemical composition of the diets are shown in table 1. The chemical composition of ingredients are shown in table 2.

Weighing was performed every 14 days, with prior fasting for 16 hours, from the beginning of the experiment until slaughter.

After 70 days in addition to the adaptation period, the animals were fed a purely liquid diet for 16 hours. The animals were slaughtered by concussion stunning, using a captive-bolt pistol with explosion cartridge, and severing of the carotid artery and jugular vein after the unconscious state was verified. The slaughter weights were $29.6,30.2,28.2,25.9$ and $25.7 \mathrm{~kg}$, to $0,25,50,75$ and $100 \%$ of replacement, respectively.

After skinning and evisceration, the head (sectioned at the atlo-occipital joint) and the feet (sectioned at the metacarpal and metatarsal joints) were removed from each

Table 1 - Ingredients and chemical composition of the experimental diets.

\begin{tabular}{|c|c|c|c|c|c|}
\hline \multirow{2}{*}{ Ingredients (\% DM) } & \multicolumn{5}{|c|}{ Substitution rate $(\%)$} \\
\hline & 0 & 25 & 50 & 75 & 100 \\
\hline Tifton hay & 50.0 & 50.0 & 50.0 & 50.0 & 50.0 \\
\hline Corn germ meal & 0.0 & 6.0 & 12.0 & 18.0 & 24.0 \\
\hline Corn & 24.0 & 18.0 & 12.0 & 6.0 & 0.0 \\
\hline Soybean meal & 14.5 & 14.0 & 13.5 & 13.0 & 12.5 \\
\hline Wheat bran & 10.0 & 10.5 & 11.0 & 11.5 & 12.0 \\
\hline Sodium chloride & 0.5 & 0.5 & 0.5 & 0.5 & 0.5 \\
\hline Mineral mix & 1.0 & 1.0 & 1.0 & 1.0 & 1.0 \\
\hline \multicolumn{6}{|c|}{ Chemical composition } \\
\hline Dry matter $(\mathrm{DM})^{*}$ & 872.0 & 874.1 & 876.2 & 878.3 & 880.4 \\
\hline Crude protein ${ }^{1}$ & 143.3 & 143.4 & 143.5 & 143.6 & 143.7 \\
\hline Ether extract ${ }^{1}$ & 31.7 & 53.8 & 76.0 & 98.1 & 120.3 \\
\hline Mineral matter ${ }^{1}$ & 57.1 & 56.6 & 56.2 & 55.8 & 55.3 \\
\hline Neutral detergent fiber ${ }^{1}$ & 440.9 & 463.7 & 486.6 & 509.4 & 532.2 \\
\hline Acid detergent fiber ${ }^{1}$ & 189.2 & 196.2 & 203.1 & 210.1 & 217.1 \\
\hline Lignin $^{1}$ & 27.0 & 28.2 & 29.3 & 30.4 & 31.5 \\
\hline Neutral detergent insoluble protein ${ }^{1}$ & 33.3 & 35.1 & 37.0 & 38.9 & 40.7 \\
\hline $\mathrm{TDN}^{1}$ & 0.744 & 0.786 & 0.627 & 0.555 & 0.530 \\
\hline
\end{tabular}


animal, and hot carcass weight $(\mathrm{HCW})$ was registered. The carcasses were placed in a refrigerated chamber and left to cool for 24 hours at $\pm 4{ }^{\circ} \mathrm{C}$ hanging from hooks by the Achilles tendon with the metatarsal joints spaced $14 \mathrm{~cm}$ apart. After the refrigeration period, the carcasses were cut in half, and the left half of the carcasses was weighed and cut into six anatomical regions according to the methodology Cezar and Sousa (2007), resulting in the following commercial meat cuts: neck, shoulder, leg, loin, ribs and sawcut. The left legs of each animal were labeled, vacuum packed in high density polyethylene bags, and frozen at $-18{ }^{\circ} \mathrm{C}$ for subsequent laboratory analyses.

The chemical composition was calculated for the Semimembranosus muscle, which was crushed and homogenized in a blender and then dried for subsequent determination of moisture (Aoac, 1995 \#925.04), crude protein (Aoac, 1995 \#981.10), ether extract (Aoac, 1995 \#935.38) and ash (Aoac, 1995 \#938.08).

The fatty acids present at the lipid extract were characterized according to Hartman and Lago (1973). The lipid extract was obtained from an aliquot of Semimembranosus muscle according to Folch, Less and Stanley (1957). The fatty acid esters were identified and quantified using a gas chromatographer (VARIAN 430-GC, California, USA) coupled to a flame ionization detector (FID), with a fused-silica capillary column (CP WAX $52 \mathrm{CB}$, VARIAN), $60 \mathrm{~m} \times 0.25 \mathrm{~mm}$, with $0.25 \mu \mathrm{m}$ film thickness. Helium was used as the carrier gas $(1 \mathrm{~mL} /$ min). The initial oven temperature was $100^{\circ} \mathrm{C}$, with a $2.5^{\circ} \mathrm{C}$ per minute increase to $240^{\circ} \mathrm{C}$, remaining for 20 minutes. The injector and detector temperatures were maintained at $250^{\circ} \mathrm{C}$ and $260^{\circ} \mathrm{C}$, respectively. Chromatograms were registered using the Galaxie Chromatography Data System type software. Fatty acids were identified by comparing the methyl ester retention times for the samples with the corresponding retention times for the Supelco ME19-Kit standards (Fatty Acid Methyl Esters C6-C22). The fatty acid results were quantified normalizing the areas for the methyl esters, and expressed as an area percentage.

Analysis of the variables was performed by adopting a model relative to the completely randomized design, according to the following model:

$$
Y_{i j}=\mu+T_{i}+\beta\left(X_{i j}-X\right)+e_{i j}
$$

where $\mathrm{Y}_{\mathrm{ij}}=$ observed value of the dependent variable; $\mu=$ overall mean; $\mathrm{T}_{\mathrm{i}}=$ effect of treatment $\mathrm{i}(\mathrm{i}=1$ to 5$) ; \beta\left(\mathrm{X}_{\mathrm{ij}}-\mathrm{X}\right)$ $=$ covariate effect (initial weight); and $\mathrm{e}_{\mathrm{ij}}=$ experimental error. The data were tabulated and subsequently subjected to analysis of covariance using the PROC MIXED procedures of SAS statistical package (Sas, 2004).

\section{RESULTS AND DISCUSSION}

The meat moisture, ashes, crude protein and ether extract concentrations were not influenced by the substitution (Table 3).

According to Ortiz et al. (2005), the chemical composition of sheep meat can vary with the age of the animal, slaughter weight, fat concentration, and type of diet, with average values of $75 \%$ humidity, $19.6 \%$ crude protein, $2.5 \%$ ethereal extract, and $1.2 \%$ ashes. Except for ether extract, the values obtained in this study corroborate those cited by the authors.

Carvalho and Medeiros (2010) observed no effect of diets containing high levels of energy on the proximate composition of meat from sheep terminated in confinement. Costa et al. (2012) analyzed the chemical composition of Santa Inês sheep meat and found values close to the results of the present study: $75.6 \%$ humidity, $2.5 \%$ ethereal extract, $20.7 \%$ protein, and $1.02 \%$ ashes.

Table 2 - Chemical composition of ingredients.

\begin{tabular}{ccccccrr}
\hline Ingredient & $\mathrm{DM}$ & $\mathrm{EE}$ & \multicolumn{1}{c}{$\mathrm{CP}^{1}$} & $\mathrm{NDF}^{1}$ & $\mathrm{TCHO}^{1}$ & NFC $^{1}$ & LIG $^{1}$ \\
\hline Tifton hay & 857.6 & 19.3 & 86.2 & 704.6 & 820.0 & 115.4 & 44.9 \\
Corn germ meal & 907.0 & 425.4 & 107.2 & 441.1 & 454.2 & 13.1 & 22.3 \\
Corn & 871.8 & 56.5 & 82.4 & 109.1 & 842.5 & 733.4 & 5.7 \\
Soybean meal & 871.2 & 33.5 & 441.4 & 166.7 & 454.9 & 288.2 & 2.3 \\
Wheat bran & 880.1 & 36.2 & 164.0 & 382.2 & 747.9 & 365.7 & 28.2 \\
Sodium chloride & 990.0 & - & - & - & - & - & - \\
Mineral mix & 990.0 & - & - & - & - & - & - \\
\hline
\end{tabular}

*Dry matter (g/kg natural matter); ${ }^{1} \mathrm{~g} / \mathrm{kg}$ dry matter; $\mathrm{EE}=$ ether extract; $\mathrm{CP}=$ crude protein; $\mathrm{NDF}=$ neutral detergent fiber; $\mathrm{TCHO}$ $=$ total carbohydrates; NFC $=$ non-fibrous carbohydrates; $\mathrm{LIG}=$ lignin. 
Hood and Thornton (1979) found that there is an increase in the number of fat cells in sheep Santa Ines in the growth phase between 28 and 45 $\mathrm{kg}$ body weight. Despite increasing levels of lipids in the diet, in this study, the confinement time was pre-set at $70 \mathrm{~d}$; therefore, the absence of effect on ether extract content could be a consequence of the slaughter occurring before muscle growth has reached its plateau, namely before the adipose tissue started its development.
Thirty different fatty acids were identified in the analysis of the lipid fraction, of which 16 were saturated (Table 4), eight monounsaturated (Table 5), and six polyunsaturated (Table 6). Of the saturated fatty acids, there was a linear decrease in palmitic $(\mathrm{C} 16: 0)$ and margaric (C17:0) acids and a linear increase in stearic (C18:0) and lauric (C12:0) acids, with increasing levels of substitution of corn by corn germ meal (CGM).

Palmitic (C16:0), stearic (C18:0) and oleic (C18:1 n9) acids were the major components of the lipid fraction.

Table 3 - Chemical composition of meat.

\begin{tabular}{|c|c|c|c|c|c|c|c|}
\hline \multirow{2}{*}{ Item $(g / 100 g)$} & \multicolumn{5}{|c|}{ Substitution rate $(\%)$} & \multirow{2}{*}{ SEM $^{\mathrm{a}}$} & \multirow{2}{*}{ P-value } \\
\hline & 0 & 25 & 50 & 75 & 100 & & \\
\hline Moisture & 76.14 & 76.15 & 75.89 & 76.28 & 76.37 & 0.099 & 0.14 \\
\hline Ash & 1.19 & 1.20 & 1.26 & 1.26 & 1.15 & 0.025 & 0.15 \\
\hline Crude protein & 20.36 & 20.57 & 20.42 & 20.23 & 20.13 & 0.105 & 0.22 \\
\hline Ether extract & 1.86 & 2.00 & 2.08 & 1.92 & 2.18 & 0.060 & 0.21 \\
\hline
\end{tabular}

${ }^{a} \mathrm{SEM}=$ standard error of the mean.

Table 4 - Profile of saturated fatty acids (\% area) in the semimembranosus muscle of Santa Inês sheep fed with corn germ meal in substitution of corn.

\begin{tabular}{|c|c|c|c|c|c|c|c|c|c|}
\hline \multirow{2}{*}{$\mathrm{SFA}^{\mathrm{a}}$} & \multicolumn{5}{|c|}{ Substitution rates (\%) } & \multirow{2}{*}{ SEM $^{b}$} & \multicolumn{2}{|c|}{ P-value ${ }^{c}$} & \multirow{2}{*}{$\mathrm{r}^{2 \mathrm{~d}}$} \\
\hline & 0 & 25 & 50 & 75 & 100 & & $\mathrm{~L}$ & Q & \\
\hline C6:0 & 0.00 & 0.00 & 0.10 & 0.03 & 0.00 & 0.020 & 0.13 & 0.20 & - \\
\hline $\mathrm{C} 8: 0$ & 0.03 & 0.01 & 0.11 & 0.10 & 0.00 & 0.024 & 0.15 & 0.21 & - \\
\hline C9:0 & 0.01 & 0.01 & 0.00 & 0.08 & 0.00 & 0.005 & 0.19 & 0.13 & - \\
\hline $\mathrm{C} 10: 0$ & 0.11 & 0.01 & 0.13 & 0.07 & 0.09 & 0.004 & 0.06 & 0.26 & - \\
\hline C12:0 & 0.13 & 0.13 & 0.18 & 0.17 & 0.17 & 0.007 & 0.04 & 0.21 & 0.64 \\
\hline C14:0 & 1.86 & 1.47 & 1.84 & 1.39 & 1.49 & 0.061 & 0.08 & 0.11 & - \\
\hline C15:0 & 0.32 & 0.27 & 0.32 & 0.26 & 0.27 & 0.010 & 0.21 & 0.24 & - \\
\hline $\mathrm{C} 16: 0$ & 21.19 & 18.92 & 19.95 & 16.39 & 18.32 & 0.354 & 0.004 & 0.21 & 0.53 \\
\hline $\mathrm{C} 17: 0$ & 0.86 & 0.67 & 0.58 & 0.43 & 0.40 & 0.026 & $<0.001$ & 0.26 & 0.95 \\
\hline C18:0 & 15.41 & 17.73 & 19.59 & 19.14 & 19.74 & 0.527 & 0.02 & 0.21 & 0.77 \\
\hline C19:0 & 0.54 & 0.31 & 0.37 & 1.19 & 0.72 & 0.118 & 0.16 & 0.19 & - \\
\hline C20:0 & 0.99 & 0.88 & 0.75 & 0.51 & 0.65 & 0.130 & 0.27 & 0.18 & - \\
\hline $\mathrm{C} 21: 0$ & 0.04 & 0.02 & 0.02 & 1.02 & 0.07 & 0.184 & 0.30 & 0.14 & - \\
\hline $\mathrm{C} 22: 0$ & 1.23 & 0.58 & 1.06 & 3.75 & 1.88 & 0.411 & 0.14 & 0.19 & - \\
\hline C23:0 & 3.28 & 3.48 & 3.84 & 5.29 & 5.08 & 0.599 & 0.21 & 0.11 & - \\
\hline $\mathrm{C} 24: 0$ & 0.46 & 0.22 & 0.16 & 0.49 & 0.37 & 0.052 & 0.24 & 0.17 & - \\
\hline Total SFA & 46.44 & 44.79 & 48.99 & 50.39 & 49.25 & 0.800 & 0.06 & 0.15 & - \\
\hline
\end{tabular}

${ }^{\mathrm{a}} \mathrm{SFA}=$ saturated fatty acids; ${ }^{\mathrm{b}} \mathrm{SEM}=$ standard error of mean; ${ }^{\mathrm{c}} \mathrm{L}=$ linear effect, $\mathrm{Q}=$ quadratic effect; ${ }^{\mathrm{d}} \mathrm{r}^{2}=$ coefficient determination. 
This finding is in accordance with the available literature on the lipid profile of sheep meat, and it confirms that these fatty acids can compose up to $90 \%$ of the lipid profile of ruminant meat (Gaili; Ali, 1985).

The decrease in food palmitic acid is relatively important for human health because it is directly related with LDL-cholesterol blood levels (Lima et al., 2000). According to Cenkvàri et al. (2005), the inclusion of lipids in the diet at levels higher than 5\% (based on dry matter) is related to changes in patterns of rumen fermentation, with consequences on fiber digestibility, which could result in lower production of acetate. In sheep, smaller amounts of acetate reduce the deposition of palmitic acid (Church, 1993). The increase in stearic acid concentrations (Table 4) does not have negative consequences; because it does not possess unsaturations in its chain, C18:0 is considered neutral (Maia et al., 2012) and does not have a hypercholesterolemic effect (Santos Filho et al., 2001). Although an effect of the tested diet substitution on some fatty acids was observed, there was no influence on the total saturated fatty acids, whose values were very close to the values previously reported for Santa Inês male sheep (Madruga et al., 2006; Madruga et al., 2008).

The total monounsaturated fatty acids decreased linearly with the percent substitution, due to the decrease in oleic acid, the main monounsaturated fatty acid in sheep meat (Table 5).

About the monounsaturated fatty acids, it is possible that the decrease in $\mathrm{C} 18: 1$ concentrations is strongly related to the lipid profile of corn oil. The concentrations of C18:0 in corn oil have been reported to be high and to correspond exactly to twice the $\mathrm{C} 18: 1 \mathrm{n} 9$ concentration (Ribeiro et al., 2008). Thus, the increase in the consumption of corn oil via CGM may therefore explain the lower C18:1 $\mathrm{n} 9$ deposition in the meat of sheep that consumed CGM instead of corn, as well as the increase of C18:0 concentrations discussed above. The process of biohydrogenation, occurring at the rumen, may partly explain the results obtained for oleic and stearic acids. However, Beam et al. (2000) reported that the increase in C18:2 rumen concentrations, which most likely resulted from increased CGM consumption, tends to favor incomplete biohydrogenation, inhibiting the step that converts $\mathrm{C} 18: 1$ into $\mathrm{C} 18: 0$ and leading to the accumulation of intermediates in the process, especially oleic acid.

There was linear increase for the linoleic acid (C18:2 n6), conjugated linoleic acid (isomer C18:2 9c $11 \mathrm{t}$ ) and total polyunsaturated fatty acids concentrations (Table 6).

Corn oil is rich in polyunsaturated fatty acids, mostly C18:2, and $\omega-6$ acids (Ribeiro et al., 2008). The increase in the supply of CGM, rich in oil, led to the increase of polyunsaturated fatty acids in the diet. This abundance could explain the linear increase observed for the linoleic acid (C18:2 n6) and conjugated linoleic acid (isomer C18:2 $9 \mathrm{c} 11 \mathrm{t})$ concentrations. This increase, in turn, resulted in an increase in total polyunsaturated fatty acids. Based on the principle that a portion of the polyunsaturated fatty acids supplied escape biohydrogenation in the rumen, some authors considered that a strategy to enrich the meat of ruminants with polyunsaturated fatty acids could be to supply them with feed containing lipids rich in those compounds (Cooper et al., 2004; Elmore et al.,

Table 5 - Profile of monounsaturated fatty acids (\% area) in the semimembranosus muscle of Santa Inês sheep fed corn germ meal in substitution of corn.

\begin{tabular}{|c|c|c|c|c|c|c|c|c|c|}
\hline \multirow{2}{*}{ MUFA $^{\mathrm{a}}$} & \multicolumn{5}{|c|}{ Substitution rates (\%) } & \multirow{2}{*}{$\mathrm{SEM}^{\mathrm{b}}$} & \multicolumn{2}{|c|}{ P-value ${ }^{c}$} & \multirow{2}{*}{$\mathrm{r}^{2 \mathrm{~d}}$} \\
\hline & 0 & 25 & 50 & 75 & 100 & & $\mathrm{~L}$ & Q & \\
\hline C14:1 & 0.06 & 0.03 & 0.06 & 0.02 & 0.06 & 0.006 & 0.02 & 0.31 & 0.54 \\
\hline C15:1 & 1.59 & 1.87 & 1.60 & 1.35 & 1.40 & 0.074 & 0.10 & 0.13 & - \\
\hline $\mathrm{C} 16: 1$ & 1.63 & 1.30 & 1.28 & 1.08 & 1.06 & 0.059 & 0.005 & 0.09 & 0.87 \\
\hline $\mathrm{C} 17: 1$ & 0.49 & 0.39 & 1.32 & 0.19 & 0.13 & 0.204 & 0.12 & 0.26 & - \\
\hline $\mathrm{C} 18: 1 \mathrm{n} 9$ cis & 40.35 & 39.38 & 33.72 & 31.96 & 31.21 & 0.985 & 0.002 & 0.11 & 0.91 \\
\hline C18:1 n9 trans & 0.20 & 0.22 & 0.37 & 0.31 & 0.47 & 0.034 & 0.02 & 0.21 & 0.82 \\
\hline $\mathrm{C} 18: 1 \mathrm{n} 11$ & 2.09 & 2.19 & 2.87 & 2.97 & 4.43 & 0.223 & 0.003 & 0.27 & 0.85 \\
\hline C20:1 n9 & 0.36 & 0.25 & 0.29 & 0.77 & 0.54 & 0.079 & 0.13 & 0.14 & - \\
\hline Total MUFA & 46.76 & 45.61 & 41.51 & 38.65 & 39.24 & 0.985 & 0.004 & 0.15 & 0.89 \\
\hline
\end{tabular}

${ }^{\mathrm{a} M U F A}=$ monounsaturated fatty acids; ${ }^{\mathrm{b}} \mathrm{SEM}=$ standard error of mean; ${ }^{\mathrm{c}} \mathrm{L}=$ linear effect, $\mathrm{Q}=$ quadratic effect; ${ }^{\mathrm{d}} \mathrm{r}^{2}=$ coefficient determination . 
2005). The results of this study are in accordance with that hypothesis.

The concentration of C18:2 9c 11t, a CLA isomer, increased considerably with increased CGM supply. This increase is most likely related to the increase in linoleic acid supply with the diet, one of the main CLA precursors (Santos et al., 2001), which is converted into CLA via isomerization (Blankson et al., 2000). It should be highlighted that the ingestion of CLA has been recommended by nutritionists, due to the bioactive properties of these compounds, especially their anticarcinogenic and antioxidant properties, in addition to the beneficial effects on cardiovascular diseases, diabetes and the immune system (Blankson et al., 2000; AbuGhazaleh et al., 2001).

A decreasing linear effect for the ratio between monounsaturated and saturated fatty acids and an increasing linear effect for the polyunsaturated:saturated, and $\omega-6: \omega-3$ ratios were observed (Table 7).

The relationships among fatty acids (Table 6) were quantified with the goal of evaluating and identifying the risk factor of foods in relation to the cholesterol plasma levels in humans (Arruda et al., 2012). These results are most likely associated with the decrease in total monounsaturated fatty acids and the higher diet supply of lipids rich in polyunsaturated fatty acids. Ponnampalam et al. (2002) also observed an increase in the $\omega-6: \omega-3$ ratio of sheep meat when the supply of lipids rich in $\omega-6$ in the diet was increased.

Raes, Smet and Demeyer (2004) reported that the polyunsaturated / saturated ratio in human food should be higher than 0.7. Although the supply of CGM increased this ratio, the values observed in this study were still far from ideal. However, they were similar to previously

Table 6 - Profile of polyunsaturated fatty acids (\% area) in the semimembranosus muscle of Santa Inês sheep fed corn germ meal in substitution of corn.

\begin{tabular}{|c|c|c|c|c|c|c|c|c|c|}
\hline \multirow{2}{*}{ PUFA $^{a}$} & \multicolumn{5}{|c|}{ Substitution rates $(\%)$} & \multirow{2}{*}{$\mathrm{SEM}^{\mathrm{b}}$} & \multicolumn{2}{|c|}{ P-value } & \multirow{2}{*}{$\mathrm{r}^{2 \mathrm{~d}}$} \\
\hline & 0 & 25 & 50 & 75 & 100 & & $\mathrm{~L}$ & Q & \\
\hline $\mathrm{C} 18: 2 \mathrm{n} 6 \mathrm{cis}$ & 4.90 & 7.91 & 7.61 & 8.55 & 9.22 & 0.371 & 0.002 & 0.28 & 0.79 \\
\hline $\mathrm{C} 18: 2 \mathrm{n} 6$ trans & 0.26 & 0.14 & 0.09 & 0.87 & 0.14 & 0.159 & 0.11 & 0.23 & - \\
\hline $\mathrm{C} 18: 3 \mathrm{n} 3$ & 0.12 & 0.08 & 0.24 & 0.24 & 0.05 & 0.037 & 0.27 & 0.16 & - \\
\hline $\mathrm{C} 18: 29 \mathrm{c} 11 \mathrm{t}$ & 0.54 & 0.67 & 0.84 & 0.78 & 1.47 & 0.079 & 0.002 & 0.20 & 0.76 \\
\hline $\mathrm{C} 20: 4 \mathrm{n} 3$ & 0.51 & 0.10 & 0.08 & 0.06 & 0.09 & 0.084 & 0.16 & 0.23 & - \\
\hline $\mathrm{C} 22: 6 \mathrm{n} 3$ & 0.47 & 0.68 & 0.62 & 0.44 & 0.53 & 0.043 & 0.11 & 0.09 & - \\
\hline Total PUFA & 6.81 & 9.59 & 9.50 & 10.95 & 11.50 & 0.384 & 0.001 & 0.12 & 0.87 \\
\hline
\end{tabular}

${ }^{\mathrm{a}} \mathrm{PUFA}=$ polyunsaturated fatty acids; ${ }^{\mathrm{b}} \mathrm{SEM}=$ standard error of mean; ${ }^{\mathrm{c}} \mathrm{L}=$ linear effect, $\mathrm{Q}=$ quadratic effect; ${ }^{\mathrm{d}}{ }^{2}=$ coefficient determination.

Table 7 - Means of relations between saturated, monounsaturated and polyunsaturated fatty acids in the semimembranosus muscle of Santa Inês sheep fed corn germ meal in substitution of corn.

\begin{tabular}{|c|c|c|c|c|c|c|c|c|c|}
\hline \multirow{2}{*}{ Relations } & \multicolumn{5}{|c|}{ Substitution rates (\%) } & \multirow{2}{*}{ SEM $^{\mathrm{a}}$} & \multicolumn{2}{|c|}{ P-value ${ }^{b}$} & \multirow{2}{*}{$\mathrm{r}^{2 \mathrm{c}}$} \\
\hline & 0 & 25 & 50 & 75 & 100 & & $\mathrm{~L}$ & Q & \\
\hline MUFA : SFA $^{d}$ & 1.02 & 1.03 & 0.86 & 0.78 & 0.81 & 0.033 & 0.01 & 0.24 & 0.82 \\
\hline PUFA : $\mathrm{SFA}^{\mathrm{e}}$ & 0.15 & 0.21 & 0.19 & 0.22 & 0.24 & 0.008 & 0.007 & 0.19 & 0.73 \\
\hline DFA $^{\mathrm{f}}$ & 68.98 & 72.93 & 70.60 & 68.74 & 70.49 & 0.852 & 0.13 & 0.28 & - \\
\hline$\omega 6: \omega 3$ & 5.48 & 9.40 & 8.60 & 12.84 & 14.64 & 0.650 & $<0.001$ & 0.18 & 0.91 \\
\hline$h: H^{g}$ & 1.98 & 2.33 & 1.91 & 2.32 & 2.06 & 0.034 & 0.17 & 0.21 & - \\
\hline$(\mathrm{C} 18: 0+\mathrm{C} 18: 1) / \mathrm{C} 16: 0$ & 2.75 & 3.15 & 2.86 & 3.30 & 3.06 & 0.047 & 0.07 & 0.18 & - \\
\hline
\end{tabular}

${ }^{\mathrm{a}} \mathrm{SEM}=$ standard error of mean; ${ }^{\mathrm{b}} \mathrm{L}=$ linear effect, $\mathrm{Q}=$ quadratic effect; ${ }^{\mathrm{c}} \mathrm{r}^{2}=$ coefficient determination; ${ }^{\mathrm{d}} \mathrm{MUFA}: \mathrm{SFA}=$ relation between monounsaturated and saturated fatty acids; ${ }^{\mathrm{e} P U F A}: \mathrm{SFA}=$ relation between polyunsaturated and saturated fatty acids; ${ }^{\mathrm{f}} \mathrm{DFA}=\mathrm{desirable}$ fatty acids; ${ }^{\mathrm{h}} \mathrm{h}: \mathrm{H}=$ ratio of hypocholesterolemic and hypercholesterolemic fatty acids $(\mathrm{C} 18: 1 \mathrm{cis} 9+\mathrm{C} 18: 2 \mathrm{n} 6) /(\mathrm{C} 14: 0+\mathrm{C} 16: 0)$. 
reported results for Santa Inês sheep (Madruga et al., 2008; Arruda et al., 2012; Costa et al., 2009; Maia et al., 2012). According to Herdmann et al. (2010), the $\omega-6: \omega-3$ ratio values should be between $4: 1$ and $6: 1$. It is also important that there is an equilibrium between the two quantities because the same enzymes are involved in the synthesis of $\omega-3$ and $\omega-6$ derivates, the preference order of the substrates by the enzymes being: omega- $3>$ omega- $6>$ omega-9 (Lima Junior et al., 2011). The high ratio obtained in the present study was due to the high dietary supply of $\omega-6$ fatty acids and indicates that the diet supply of lipids rich in these compounds is efficient in enriching sheep meat with $\omega-6$ acids.

The ratio $(\mathrm{C} 18: 0+\mathrm{C} 18: 1) / \mathrm{C} 16: 0$ has been reported to describe the beneficial effects of the different types of lipids (Maia et al., 2012), and should be between 2 and 3 in lamb meat (Banskalieva, Sahlu, Goetsch, 2000). Therefore, although it was not influenced by the tested substitution, the values obtained may be considered satisfactory, confirming the quality of the lipid fraction of Santa Inês sheep meat. The desirable fatty acids did not vary according to the experimental diets and were in accordance with the values reported by Madruga et al. (2008). The ratio between hypocholesterolemic and hypercholesterolemic fatty acids was not influenced by the substitution and was similar to the ratios obtained by Arruda et al. (2012) for Santa Inês sheep.

\section{CONCLUSIONS}

The replacement of corn by corn germ meal in the diet of confined Santa Inês sheep did not influence the chemical composition of the meat. Corn germ meal improved the nutritional quality of the lipid fraction, enriching it in compounds beneficial for human health.

\section{REFERENCES}

ABU-GHAZALEH, A.A.; SCHINGOETHE, D.J.; HIPPEN, A.R. Conjugated linoleic acid and other beneficial fatty acids in milk fatty from cows fed soybean meal, fish meal, or both. Journal of Dairy Science. 84(8):1845-1850, 2001.

AOAC. Official Methods of Analysis of the Association of Official Analytical Chemistry. 16th Ed., AOAC International, Washington, USA. 1995.

ARRUDA, P.C.L. et al. Perfil de ácidos graxos no Longissimus dorsi de cordeiros Santa Inês alimentados com diferentes níveis energéticos. Semina: Ciencias Agrárias. 33(3):1229-1240, 2012.

BAS, P. et al. Effect of level of linseed on fatty acid composition of muscles and adipose tissues of lambs with emphasis on trans fatty acids. Meat Science. 77(4):678-688, 2007.

BANSKALIEVA, V.; SAHLU, T.; GOETSCH, A.L. Fatty acid composition of goat muscles and fat depots: a review. Small Ruminant Research. 37(1):255-268, 2000 .

BEAM, T.M. et al. Effects of amount and source of fat on the rates of lipolysis and biohydrogenation of fatty acids in ruminal contents. Journal of Dairy Science. 83(11):2564-2573, 2000.

BLANKSON H. et al. Conjugated linoleic acid reduces body fat mass in overweight and obese humans. The Journal of Nutrition. 130(12):2943-2948, 2000.

CARVALHO, S.; MEDEIROS, L.M. Características de carcaça e composição da carne de cordeiros terminados em confinamento com dietas com diferentes níveis de energia. Revista Brasileira de Zootecnia. 39(6):12951302, 2010.

CEZAR, M.F.; SOUSA, W.H. Carcaças ovinas e caprinas: obtenção, avaliação e classificação. Campina Grande: Editora Universidade Federal de Campina Grande, 2007.120p.

CENKVÀRI, É. et al. Investigation on the effects of Casoaps of oil linseed on rumen fermentation in sheep on milk composition of goats. Journal of Animal Physiology and Animal Nutrition. 89 (1):172-178, 2005.

CHURCH, C.D. 1993. El rumiante: fisiología digestiva y nutrición. Zaragoza: Editora Acribia, 1993. 641p.

COOPER, S.L. et al. Manipulation of the $n-3$ polyunsaturated fatty acid content of muscle and adipose tissue in lambs. Journal of Animal Science. 82(5):1461-1470, 2004.

COSTA, R.G. et al. Lipid profile of lamb meat from different genotypes submitted to diets with different energy levels. Revista Brasileira de Zootecnia. 38(3):532-538, 2009. 
COSTA, R.G. et al. Meat quality of Santa Inês sheep raised in confinement with diet containing cactus pear replacing corn. Revista Brasileira de Zootecnia. 41(2):432-437, 2012.

ELMORE, J.S. et al. Dietary manipulation of fatty acid composition in lamb meat and its effect on the volatile aroma compounds of grilled lamb. Meat Science. 69(2):233-242, 2005.

FOLCH, J.; LESS, M.; STANLEY, S.A. Simple method for the isolation and purification of total lipids from animal tissues. The Journal of Biological Chemistry. 226(1):497-509, 1957.

GAILI, E.S.; ALI, A.E. Meat from Sudan desert sheep and goats: part 2 - composition of the muscular and fatty tissues. Meat Science. 13(4):229-236, 1985.

HARTMAN, L.; LAGO, R.C.A. Rapid preparation of fatty acids methyl esters. Laboratory Practice. 22(6):475-476, 1973.

HERDMANN, A. et al. How do n-3 fatty acid (shorttime restricted vs unrestricted) and n-6 fatty acid enriched diets affect the fatty acid profile in different tissues of German Simmental bulls? Meat Science. 86(3):712-719, 2010.

HOOD, R.L.; THORNTON, R.F. The cellularity of ovine adipose tissue. Australian Journal of Agricultural Research. 30(1):153-161, 1979.

LIMA, F.E.L. et al. Ácidos graxos e doenças cardiovasculares: uma revisão. Revista de Nutrição. 13(2):73-80, 2000.

LIMA JÚNIOR, D.M. et al. Alimentos funcionais de origem animal. Revista Verde de Agroecologia e Desenvolvimento Sustentável. 6(2):30-40, 2011.

MAIA, M.O. et al. Efeito do genótipo sobre a composição química e o perfil de ácidos graxos da carne de borregas. Revista Brasileira de Zootecnia. 41(4):986-992, 2012.

MADRUGA, M.S. et al. Efeito do genótipo e do sexo sobre a composição química e o perfil de ácidos graxos da carne de cordeiro. Revista Brasileira de Zootecnia. 35(4):1838-1844, 2006.
MADRUGA, M.S. et al. Efeito de dietas com níveis crescentes de caroço de algodão integral sobre a composição química e o perfil de ácidos graxos da carne de cordeiros Santa Inês. Revista Brasileira de Zootecnia. 37(8):1496-1502, 2008.

ORTIZ, J.S. et al. Medidas objetivas das carcaças e composição química do lombo de cordeiros alimentados e terminados com três níveis de proteína bruta em creep feeding. Revista Brasileira de Zootecnia. 34(6):23822389, 2005.

PONNAMPALAM, E.N. et al. Effects of dietary lipid type on muscle fatty acid composition, carcass leanness, and meat toughness in lambs. Journal of Animal Science. 80(3):628-636, 2002.

RAES, K.; SMET, S. DE.; DEMEYER, D. Effect of dietary fatty acids on incorporation of long chain polyunsaturated fatty acids and conjugated linoleic acid in lamb, beef and pork meat: a review. Animal Feed Science and Technology. 113(4):199-221, 2004.

RIBEIRO, P.A.P. et al. Efeito do uso de óleo na dieta sobre a lipogênese e o perfil lipídico de tilápias-do-nilo. Revista Brasileira de Zootecnia. 37(8):1331-1337, 2008.

RIOUX, V.; LEGRAND, P. Saturated fatty acids: simple molecular structures with complex cellular functions.

Current Opinion in Clinical Nutrition \& Metabolic Care. 10(6):752-775, 2007.

SANTOS, F.L. et al. Efeito da suplementação de lipídios na ração sobre a produção de ácido linoléico conjugado (CLA) e a composição da gordura do leite de vacas. Revista Brasileira de Zootecnia. 30(6):1931-1938, 2001.

SANTOS FILHO, J.M. et al. Lipídios em carnes de animais utilizados para consumo humano: uma revisão. Ciência Animal. 11(2):87-100, 2001.

SAS INSTITUTE. SAS Systems for Windows, Version 9.1. SAS Institute Inc., Cary, NC, USA, 2004.

SILVA, E.C. et al. Substituição do fubá de milho por gérmen integral de milho na dieta de ovinos. Pesquisa Agropecuária Brasileira. 48(4):442-449, 2013.

WOOD, J.D. et al. Effects of fatty acids on meat quality: A review. Meat Science. 66(1):21-32, 2004. 